\title{
Discursive Strategies and Speech Acts in Political Discourse of Najib and Modi
}

\section{OPEN ACCESS}

Manuscript ID:

EDU-2020-08033168

Volume: 8

Issue: 3

Month: June

Year: 2020

P-ISSN: $2320-2653$

E-ISSN: 2582-1334

Received: 24.04 .2020

Accepted: 21.05.2020

Published: 01.06.2020

Citation:

Ramanathan, Renugah, et al. "Discursive Strategies and Speech Acts in Political Discourse of Najib and Modi." Shanlax International Journal of Education, vol. 8, no. 3, 2020, pp. 34-44.

DOI:

https://doi.org/10.34293/ education.v8i3.3168

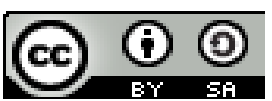

This work is licensed under a Creative Commons Attribution-ShareAlike 4.0 International License

\section{Renugah Ramanathan}

Department of English, Faculty of Modern Languages and Communication Universiti Putra Malaysia, Selangor, Malaysia

\section{Shamala Paramasivam}

Department of English, Faculty of Modern Languages and Communication Universiti Putra Malaysia, Selangor, Malaysia

https://orcid.org/0000-0002-7213-9445

\section{Tan Bee Hoon}

Department of English Language and Communication,

Faculty of Social Science and Liberal Arts UCSI University (Kuala Lumpur Campus), Malaysia

\begin{abstract}
Election campaigns are constantly regarded as a persuasive campaign to convince the nation to vote for the leader of a country. Being said such, this study investigates the discourse of twitter of two political premiers in Asia: Former Prime Minister of Malaysia, Najib Tun Razak (henceforth, Najib) and Prime Minister Narendra Modi (henceforth, Modi), in the aspects of discursive strategies and speech acts during election campaigns. The discourse of Najib and Modi are selected due to their active participation on Twitter throughout election campaigns. The data were collected over 3 months throughout the national elections of both the countries, which were from February to April 2013 in Malaysia and January to March 2014 in India. This qualitative study employs Wodak's discursive strategies to analyze the lexical choices utilized in the election tweets and Searle's speech act taxonomy to analyze the speech acts used. The presence of two major speech acts was highlighted during the elections: commissives and directives. These two speech acts collaborated under the hood of discursive strategies of predication and perspectivation that empowered Najib and Modi to establish a strong contact with citizens while creating a sense of integrity and oneness. This study is significant as it creates political and language awareness to citizens by denoting how political figures establish power through mutual consent with citizens using Twitter. Furthermore, this study enlightens citizens on how the 140-character tool can influence the political decisionmaking of a community.
\end{abstract}

Keywords: Discursive strategies, Speech acts, Power, Persuasion, Political discourse, Twitter.

\section{Introduction}

The decision-making process in a country relies on the citizens to determine the future government and a leader. This legislative process is an important procedure to distinguish the formation of the government and the solidity of the cabinet in a country. In Asia, the two most prominent elections which were known as the social media elections took place in Malaysia on 5th May 2013 while in India, the campaign was held from 7th April to 12th May 2014. Ultimately, the national elections in Malaysia involved 15 registered parties while there was a minority of unregistered parties. The Barisan National (henceforth, BN) was a leading political party in 2013. 
Meanwhile, in India, the multi-political party system varies every five years, depending on the number of registered parties. In 2014, the Bharatiya Janata Party (henceforth, BJP) emerged as the largest contesting party in India.

Election campaigns are where ideas, beliefs, intentions, and opinions are disseminated. Being said such, the social media elections in Malaysia and India were held in various social media platforms, and one such platform that has gained much popularity and support from citizens was Twitter. This microblog is one of the well-known microblogs among world leaders, heads of states, and intergovernmental organizations. Before the social media elections in Malaysia and India, several other western countries have started employing Twitter to gain victory in elections.

The success of the 140 characters on Twitter during elections has brought about complications to the language used. The challenging use of language in Twitter permits simplified characters to be disseminated that portrayed obscure meaning to the citizens. The intended meaning of these politicians is often related to real-life scenarios. In Twitter, the overt personal involvement and the illustrations of direct speech acts highlight Najib's and Modi's commitment towards future actions in constructing a better nation and to direct citizens in voting for a better future. Hence, this study aims to investigate the political tweets of Najib and Modi in the aspects of illocutionary speech acts such as directives and commissives, which are collaborated with Wodak's discursive strategies to perceive how language is systematically used to show commitment and future directions.

\section{Review of Related Studies}

Languages that are spoken around the world serve a primary function to enable humans to speak to express their feelings while communicating accurately and effectively. In the context of pragmatics, an utterance is seen as a rich mechanism that possesses meaning beyond the scope of linguistic research. The study of speech acts is a branch of linguistics and a subfield of pragmatics, which is perceived as a mode of communication in daily life. Researchers of pragmatics, being one of the components under the field of linguistics after syntax and semantics, are interested in investigating the "relationship between linguistic forms and the users of those forms" (Yule, 1996, p. 4). Meanwhile, Fromkin and Rodman (1998) asserted that pragmatics examined the interpretation and the intended meaning of utterances in a linguistic context. However, Thomas (1995) argued that pragmatics is concerned with meaning in use that is also referred to as meaning in context.

Traditionally, speech acts were developed by Austin (1962), who perceived that utterances are the foundation of every communicative pattern. Speech acts are often found when speakers develop sets of ideas that are later channeled to the listener with an intended message, assuming that the listeners can execute the exact message delivered by the speakers. Searle (1979) proclaimed that speech acts are logical presuppositions whereby linguistic communicative functions are linked with purposeful utterances and consequent actions. According to Austin (1962), there are three prominent distinctions of utterances that are accomplished in language. Locutionary Acts are acted in speaking that produces significant linguistic expressions, hence creating direct meaning for the sentence. In the elocutionary act, Austin (1962) introduced three sub-acts which are: The phonetic act that deals with speech sound in speech units, The phatic act which is merely vocabulary and grammar stringed together to compose specific linguistic meaning, The rhetoric act performs acts about the specific expression uttered. The second form of speech acts by Austin (1962) is the illocutionary act that refers to the intended meaning of the speaker in a particular context. Perlocutionary acts, being the third dimension of Austin's (1962) speech acts branch deals with the subsequent acts that follow the illocutionary act force that often changes people physiologically.

About Austin's speech act propositions, Searle has extended the notion of speech acts by arguing that speech acts do not only involve a speaker's utterances or conveying an intended meaning in a particular context, but it also comprises of body movements and unexplained sounds. While speech acts involve various behavior and attitudes, Searle (1979) contended that speech acts only encompass definite intentions and behavior in a communicative setting. 
The following section presents the illocutionary act force, which focuses on the intended meaning.

\section{Illocutionary Speech Acts}

One of the most prominent aspects of speech acts is the 'illocutionary act' as it focuses on the intended meaning or performance of the utterer. Yule (1996) stated that the term speech act generally relates to the notion of illocutionary acts. Another prominent notion highlighted by Liedtke (1990) on illocutionary acts is that illocutionary acts represent the proposition of the real world whereby the notion of illocutionary acts are aimed at without intervening the effects of illocutionary acts which are known as perlocutionary acts. Although the notion of illocutionary acts is mostly emphasized by Searle, yet Austin had contradicting views on illocutionary acts and its propositions. About this aspect, Austin (1962) named illocutionary acts as eo ipso as they denote the performance of illocutionary acts. Austin (1962) stated that to perform an illocutionary act; the elocutionary act must be determined in the following aspects:

1. Asking or answering a question

2. Giving some information or assurance or a warning

3. Announcing a verdict or an intention

4. Pronouncing sentences

5. Making an appointment or an appeal or a criticism

6. Making an identification or giving a description

(Austin, 1962, p. 98)

On the other hand, Austin (1962) perceived illocutionary acts as an illocutionary force whereby the performance of the act is emphasized rather than the other aspects of speech acts. Besides, Austin noted that an illocutionary act would not take place unless the speaker utters meaningful utterances that require performance. Similarly, Searle (1969) asserted that illocutionary acts are related to Austin's concept of infelicity, whereby "not all the conditions are logically independent of each other. Sometimes it is worthwhile to state a condition separately even though it is, strictly speaking, entailed by another" (p. 54). A unique notion by Pandey (2008) is that an illocutionary act can be perceived as a perlocutionary act but not vice-versa. Based on the notion above, the illocutionary act is termed as securing uptake as it involves the performance of the utterer. The perception of securing uptake is based on a mutual understanding whereby there must be a connection between the hearer and the illocutionary force of the utterance (Pandey, 2008; Austin, 1962). A point to be noted here is that, without mutual agreement between both entities, the illocutionary act will be void.

Searle (1969) continued his claim that the illocutionary act is a game as it is directly carried out without specific rules but conditions that should be precise to perform the illocutionary act. The illocutionary conditions proposed by Searle (1969) are exemplified in the explicit performatives section.

\section{Searle's Speech Act Taxonomy}

Searle's version of illocutionary acts converges with Austin's (1962) category of speech acts in several aspects. However, there are several variances in Searle's taxonomy as he employed several criteria to classify the illocutionary acts. The purpose of identifying these criteria is to observe the emerging behavior within the speech acts taxonomy. Therefore, Searle constructed the three dimensions before identifying the five basic taxonomies of speech acts. The three dimensions are as follows:

- Illocutionary point or purpose: In this aspect, the ultimate purpose of the description is to determine the truth and falseness of a particular statement while committing speakers to undertake something in the future.

- The direction of fit: Words should match the real-world context.

- Speaker's psychological state: The speaker strongly believes what is said and wants things to be done according to what has been said.

Using these criteria, Searle came up with five categories of illocutionary acts that describe the action or behavior of the utterer. Assertive deals with the truth and false of a proposition that is being expressed in a situation or particular phenomenon (Searle, 1969, 1979). Searle made an emphasis on this taxonomy by stating that words such as 'belief' and 'commitment' should portray the intended determinable of the utterer rather than the determinates. This taxonomy is similar to Austin's (1962) taxonomy of speech 
acts, which are Expositives and Verdictives. About illocutionary speech acts, some of the essential components in the speech act categories are such as boasting and complaining. The function of boasting in this illocutionary point is to express the sincerity of a proposition that the speaker is proud of its actual state of affairs. Meanwhile, Vanderveken (1990) stated that complaining is to assert discontent in which the proposition is ruthless and that it may lead to sadness.

Searle's second taxonomy of illocutionary speech acts is Directives, whereby this illocutionary point attempts to get the listener to perform an action directed by the speaker (Searle, 1969, 1979). Searle further pointed out that there are two ways in which directives can be executed upon the listener, which are modest attempts and fierce attempts (Searle, 1979). A modest attempt is a polite manner in which the speaker directs the listener to perform an action whereby the fierce attempt insists or forces the listener to act. An important aspect pointed out by Searle is that actions which will be performed by the listener should be fulfilled in the future (Searle, 1979). Moreover, Searle (1979) and Thomas (1995) described the different types of verbs which are significant in this taxonomy; ask, order, command, request, beg, plead, pray, entreat, invite, permit and advise. Hence, this aspect of taxonomy is in line with Austin's (1962) speech act classification of Exercitives.

Commissions, being the third category in this taxonomy, deals with the speakers' commitment towards some future actions. Although this taxonomy is likened to Austin's taxonomy of Commisives, certain verbs listed in Austin's taxonomy is irrelevant in Searle's taxonomy of speech act (Searle, 1979) such as 'shall,' 'intend,' 'favor' and other verb forms. In this taxonomy, Searle focused on the point of promise and request that suggests the speaker some form of action. Searle's notion of commissions is not necessary to complete the actions in due course but to commit oneself to act.

The fourth category is Expressives, whereby this taxonomy "expresses the psychological state" specified in a particular situation (Searle, 1979, p. 15). Significantly, expressions are expressed when the truth of the proposition is presupposed.
For instance, "I apologize for having stepped on your toes." This portrays that the action of having stepped on toes is being done on purpose. Therefore, the expressive term of apology is unrelated in this proposition (Searle, 1979; Thomas 1995). Alternatively, this taxonomy is employed to express regret in an unintentional action and gratitude when the proposition is true. Expressions that are suitable in this taxonomy are such as congratulating, thanking, welcoming, apologizing, deploring, condoling, and more.

Declarative is the final category in Searle's speech act taxonomy whereby it defines the characteristics of the successful performance of the speaker that brings about the "correspondence between the propositional content and reality" (Searle, 1979, p. 16-17). Furthermore, when an action is being declared, it brings about an alteration in the status of the listener and therefore requires immediate action (Searle, 1979; Thomas 1995). For instance, You are fired! And I pronounce you man and wife! These statements are successful declarative statements as it denotes immediate action without providing an alternative to the listener. The upcoming section exhibits the previous studies in Searle's speech act taxonomy.

The notion of speech acts was introduced half a century ago by Austin (1962) in his work How to do Things with Words, which was further examined by Searle (1979) in one of the main branches of speech acts, which is known as illocutionary act force. Since then, there have been various studies related to the illocutionary acts in diverse domains, which outlined the intended meaning through the representation of lexical choices while there seems to be little literature in the notion of speech acts in election tweets on Twitter.

In the context of the illocutionary act force, Sotillo (2012) studied the five different types of illocutionary acts under the taxonomies of Searle's speech act classification between text message users. It was found that the usage of illocutionary acts of assertiveness was accounted for 39\%, expressive $33 \%$, directives $20 \%$, commissions $8 \%$, and the illocutionary act of declarations was not present. The illocutionary force of assertive is frequently employed as texters are willing to express and state 
the truth and fallacy of a proposition since text messages are usually shared between two users. In contrast, the privacy of the messages is being protected. Meanwhile, the act of commissions is irregularly employed as texters less likely to commit themselves to future actions.

Similarly, Ilyas and Khushi (2012) investigated the illocutionary act verbs proposed by Searle on Facebook status updates. Based on the analysis, it was reported that $33.33 \%$ of the updates were categorized as the illocutionary act of expressive as Facebook is a platform where users constantly express their feelings and emotions under various situations. On the contrary, 2.32\% of Facebook statuses are recognized as commissives, and this finding is similar to findings reported in the previous study.

Another study by Mišić Ilić and Radulović (2015) exhibited the two main forms of illocutionary speech acts which are expressive and commissive in political discourse. The employment of commissive speech acts holds the highest usage in the discourse of politicians. The emergence of explicit commissives implied the speaker's direct intention towards their commitment shortly, which is spotted in the occurrence of the modal verb 'will.' Meanwhile, the implicit speech acts were frequently employed in the speeches of political leaders, which denoted the speaker's obscure intentions.

Under the same lens, Zhang et al. (2011) explored the speech act recognition on Twitter, whereby the distribution of speech acts in line with Searle's speech act taxonomy is scrutinized on three various topics. It was found that illocutionary acts of expressiveness are commonly used across the three topics to comment and provide feedback issues discussed. Since Twitter has emerged as a microblogging tool, Twitter users have been continuously using this tool to express by commenting within 140 characters. In the same light, Nastri et al. (2006) studied the importance of Searle's speech act taxonomy in the construction of messages in an Instant Messenger on Away Messages. The report showed that the illocutionary act of assertiveness is highly employed throughout the messages as it is a convenient mode to state and assert propositions of the utterer, which tended to be informational and expressive. On the other hand, the low production of the illocutionary act of directives indicated that directives focus on getting the hearer to perform an act. Therefore, in this context, the assertion is more likely to be used compared to directives and declarations.

The present study views that Searle's taxonomy of speech acts is more insightful and systematic. Besides, Searle's taxonomy describes the actions achieved by people in a naturalistic manner. Austin's taxonomy of speech acts is overlapped with those of Searle's wherein the verb categories presented in Austin's meet the criteria of the particular speech act classes. Austin (1962, p. 151) asserts that categories of speech acts such as behabitives and expositions are ambiguous as they are cross-classified. Thus, this study considers Searle's theory of speech acts as more practical and appropriate than that of Austin's. Besides, Searle's remarkable taxonomy is well formulated as this speech act can probe into social and cultural institutional levels of reality through which human life is shaped.

\section{Wodak's (2005) Discursive Strategies}

Discourse is related to other communicative events, synchronically, and diachronically. In other words, discourse as a social act is influenced by other events that have occurred simultaneously or have taken place before. Fairclough (1992) enlightens that communicative events have different interpretations as readers and listeners possess different schemata and information and are of different social positions. About this knowledge, there is no right interpretation since propositions are dialectical. In other words, interpretations are likely to be true, but they are not flawless. Wodak's discursive strategies are meant to be a systematic way of using language. Besides, it is worth noting that Wodak's (2005) discursive strategies can be adopted to implement certain aims such as social, political, psychological, or linguistic aims. The discursive strategies are involved in the notion of positive self-presentation and negative other-presentation based on the construction of Us and Them. 


\begin{tabular}{|c|c|}
\hline $\begin{array}{c}\text { Discursive } \\
\text { Strategy }\end{array}$ & Meaning \\
\hline $\begin{array}{l}\text { Referential } \\
\text { Nomination }\end{array}$ & $\begin{array}{l}\text { This strategy is concerned with } \\
\text { the speaker's attempt to categorize } \\
\text { people into in-group and out- } \\
\text { group. }\end{array}$ \\
\hline Predication & $\begin{array}{l}\text { This strategy refers to the intention } \\
\text { of speakers to describe social } \\
\text { actors negatively and positively. } \\
\text { Metaphorical expressions are used } \\
\text { in describing people. }\end{array}$ \\
\hline Argumentation & $\begin{array}{l}\text { This strategy reveals the moments } \\
\text { when speaker attempt to legitimize } \\
\text { or justify the negative or positive } \\
\text { acts they produce. }\end{array}$ \\
\hline Perspectivation & $\begin{array}{l}\text { This strategy describes about the } \\
\text { attempt of a speaker to get his } \\
\text { audience involved throughout } \\
\text { a variety of techniques such as } \\
\text { reporting, describing, narrating or } \\
\text { quoting sentences. }\end{array}$ \\
\hline Intensification & $\begin{array}{l}\text { This strategy reveals the moment } \\
\text { when the speaker intends to } \\
\text { produce utterances implicitly or } \\
\text { explicitly. }\end{array}$ \\
\hline
\end{tabular}

It is worth noting that an aspect of discursive strategies is predication, which describes politicians' intended meaning. The aim of investigating speech acts in political discourse is to reveal how ideologies are communicated through the 140 characters on Twitter, which condensed and simplified the discourse that can be easily understood by the citizens. Notably, discursive strategies disclose how political figures manifest their future commitment and maneuver citizens to build a better future.

\section{Methodology}

The qualitative research design was employed in this study to analyze the tweets of Najib and Modi to identify illocutionary speech acts.

\section{Data Collection}

Data were collected over three months before the national elections, which were from February to April 2013 for Najib and January to March 2014 for Modi. A total of 592 tweets were collected from the official Twitter of Najib, and 545 tweets were gathered from the official profile of Modi. Thus, the total number of tweets gathered is 1137. After reading and examining the tweets, refinement of the specified data was achieved by excluding tweets that were posted in 'Malay' and 'Hindi' languages. The exclusion of tweets included 413 tweets in Malay and 10 tweets in Hindi. The exclusion process was necessary as the main concern of this study is to analyze tweets that were originally posted in English only.

\section{Data Analysis}

Speech acts involve the analysis of intended meaning in conversations and discourse analysis that investigates the election tweets and choice of words in the tweets by Najib and Modi during their electoral campaigns. In Searle's speech acts, various intended meanings were drawn from the tweets while taking into account the precise function of tweets, which represented a specific purpose of action. Besides, this study employed Wodak's (2005) discursive strategy of perspectivation, in which the speakers attempt to get their audience involved through various techniques, such as ordering, requesting, promising, and swearing. To analyze these functions of language, Searle (1979) proposed five speech act classification for the purpose of analyzing political discourse from the perspective of a speaker. However, in this study, Searle's commissives and directives speech acts are analyzed as this study aims at analyzing the intended meaning of Najib and Modi as speakers during the election campaigns. Table 2 Illustrates the Characteristics of the Speech Act Classifications with Examples.

Table 2: Searle's (1979) Classes of Speech Acts

\begin{tabular}{|c|c|c|}
\hline $\begin{array}{l}\text { Classes of } \\
\text { speech acts }\end{array}$ & Characteristics of Speech Acts & Examples \\
\hline \multirow[t]{3}{*}{ Commissives } & $\begin{array}{l}\text { Directives are used to: } \\
\quad \text { - Call upon the hearer to do something }\end{array}$ & $\begin{array}{l}\text { To suggest } \\
\text { To command }\end{array}$ \\
\hline & - Prompt hearers to take an action & $\begin{array}{l}\text { To challenge } \\
\text { To order }\end{array}$ \\
\hline & $\begin{array}{l}\text { Examples of verbs used are: propose, order, } \\
\text { direct, defy and suggest }\end{array}$ & $\begin{array}{l}\text { To request } \\
\text { To defy } \\
\text { To instruct }\end{array}$ \\
\hline \multirow[t]{2}{*}{ Directives } & $\begin{array}{l}\text { Commissives are used to: } \\
\text { - Commit the speaker to perform a future } \\
\text { Action }\end{array}$ & $\begin{array}{l}\text { To promise } \\
\text { To pledge } \\
\text { To swear } \\
\text { To guarantee }\end{array}$ \\
\hline & $\begin{array}{l}\text { Examples of verbs used are: promise adopt, } \\
\text { accommodate, advocate, warn, offer and vow }\end{array}$ & $\begin{array}{l}\text { To undertake } \\
\text { To threat } \\
\text { To vow }\end{array}$ \\
\hline
\end{tabular}

\section{Results and Discussion}

This section discusses the multiple discursive strategies utilized in the tweets of Najib and Modi 
during the 2013 and 2014 national elections. The purpose of identifying discursive strategies in the tweets of Najib and Modi is to observe how power is practiced to manipulate the citizens in democratic nations. The section identifies the two discursive strategies; perspectivation and predication, which were merged with Searle's speech act taxonomy commissives and directives.

\section{Excerpt 1: Predication, Commissives}

39 We're committed to strengthening the electoral process... we will do whatever we can to ensure that objective is met"

108 Voters have noticed the failure of the opposition to deliver their promises in Selangor. Hope they vote for a party that fulfills promises

138 More than $70 \%$ of Malaysians live in urban areas. Read about our pledges to improve urban development here.

Based on the excerpt above, the word pledge (sentence 138) is synonymous with the word commitment (sentence 39). The word pledge and commitment denote that action is solemnly undertaken to perform future actions. During the 2013 general elections in Malaysia, Najib has pledged to continue to ease the cost of living for the citizens by providing 1 Malaysia products and aid students in their schooling funds. Najib, as the leader, has vowed to continue the effort of uplifting the nation to new heights wherein Najib places his interest and the welfare of the citizens first. Apart from pledging to ease the burden of the citizens, Najib is committed to the present on-going initiatives and commits to future plans in the next five years. Among his commitments include uplifting the urban well-being, providing housing, quality healthcare services, and building a dynamic economy. Najib's ultimate purpose of faithfully engaging in long term goals is to persuade the citizens to judge and vote for $\mathrm{BN}$ in fulfilling the criteria in developing a country in a well-rounded aspect.

The word promise (sentence 108) indicates an assurance that is given to citizens that one will commit to. Najib promises that he will serve the citizens with his greatest ability in aspects such as economic, political, and social transformation, protecting democracy and human rights. Furthermore, Najib vows to achieve developed status by the year 2020 in which some of the promises are on-going and will continue. Najib's 7 promises include gradually reducing car prices, creating fair policies for all races, providing the best education system in the world, tighten armed force, freedom to practice religion in peace and harmony, increase financial assistance for citizens, and to abolish sedition act.

The speech act of commissives in the tweets of Najib is in line with those of Searle's (1979) and Misic Ilic and Radulovic (2015). They asserted that the speaker commits to perform future actions and display their direct intention of the future.

\section{Excerpt 2: Perspectivation, Directives}

46 The best is yet to come. We have done so much over the last 4 years. If you give us that mandate, we will do even better.

119 Many candidates are on Twitter to share with you their plans 4 their areas. You can follow them here:

121 Show your support for today. Get an Online Action Kit \& share them with friends on social media.

Based on the excerpt above, the word give (sentence 46) denotes providing a person something. During the 2013 national elections in Malaysia, Najib has requested the citizens to provide the mandate to rule the country. Being a leader of the country, Najib requires authority from the citizens to enable him to continue serving the citizens with the initiatives which he has been executing for the past 4 years. In this context, the positive self-presentation of Najib is being reflected as he portrays himself as the in-group who supports the citizens in various aspects (Van Dijk, 2004).

Another word that is employed by Najib is the word show (sentence 121). The word show signifies the term to manifest an action that is vivid. Being a typical politician, Najib instructs the citizens to show their support by casting their votes for the most trustworthy party in this context is the $\mathrm{BN}$ party. Besides, by directing the citizens to vote for BN, Najib indicates that there could be a difference through the actions of the citizens in voting for the party. Furthermore, when Najib gains support nationwide and through social media like Twitter, his fame increases internationally, and this enhances his chances of winning the national elections.

The word follows (sentence 119) indicates a person to act accordingly. Najib commands the 
citizens to follow his latest updates on Twitter, as this will enable them to obtain the latest updates on various events during the national elections. The command by Najib is a way to attract citizens to participate in the national elections. According to Searle's (1979) speech act, the purpose of the directives act is to persuade the hearers to complete certain act which is instructed by the citizens. Throughout the national elections, Najib has directed the citizens to be an active participant to gain success. According to Wodak (2005), the discursive strategies of perspectivation are being employed by Najib, wherein Najib, as the commander, directs the citizens to vote for the leading party to make the elections a success.

Within the concept of CDA, an interesting aspect that is worth inspecting is the emergence of various topics. The aim of investigating topics of discourse analysis is to discover the themes which are commonly highlighted during the election campaign. The emerging topics during the national elections are analyzed through Brown and Yules' (1983) topic framework about the concept of nation-building. Wodak's (2005) discursive strategies are employed to classify the topics found in the elections tweets.

\section{Excerpt 3: Predication, Commissives}

63 BJP is committed to changing India's future! This election, let us VOTE FOR INDIA

320 Himachal Pradesh needs strong rail connectivity. This will help the common people \& will enhance tourism in the state

318 BJP is committed towards all-round development of Himalayan states. Promised that what didn't happen in 60 years will happen in 60 months!

239 India will progress only if Northeast progresses. We are committed to the overall development of Northeast \& its bright youngsters.

In the excerpt above, Modi employs verbs to show future commitment towards the concept of nationbuilding. Being said such, Modi commits himself by encouraging citizens to consider the delivered message rationally and to trust future action, which will be executed. In the tweets of Modi, the emergence of the verb will (sentence 239) is synonymous with the word must, which exhibits Modi's willingness to undertake measures towards the well-being of the citizens and the all-rounded development of the nation. Besides, Modi portrays a strong assertion about the future either within or beyond one's capability. Modi has explicitly expressed his vision of the country by vowing to place India back on track and to deliver good governance.

The word promise (sentence 318 ) is synonymous with the word commitment (sentence 63) wherein Modi assures citizens by stating that he is committed to developing a modern India in all aspects and to every social class regardless of their religion and the community. In respect to the word promise and commitment, Modi has made 42 promises which are listed in the Election Manifesto. Some of his promises and commitment to nation building are strengthening the education system and improving the infrastructure of the nation. Furthermore, Modi's notion towards nation development is to lure citizens into believing in his commitment to constructing a first-class nation.

Another word that Modi utilizes is the word help (sentence 320), which denotes the attempt to provide benefit to the citizens. In this context, Modi attempts to help the citizens in various aspects that may benefit them. In the concept of nation-building, Modi is committed to the progress of the national construction throughout the election campaign in which Modi's vital motives are to succeed in the upcoming elections, gain support and trust of citizens. Thus, Modi emphasizes the type of help that will be provided in the future, and one such assistance is benefiting people across the country, especially to aid citizens in the rural section.

The words utilized by Modi, such as promise, commit, help, and will signify commissives speech acts in the tweets of Modi. This indicates that Modi, as an in-group, expresses his intention towards the concept of nation-building and describes the positive assistance that he commits to provide the citizens. This speech act is about the Searle (1979) speech act classification wherein the illocutionary act denotes the real intentions of Modi in committing to the reality of the concept of nation-building. Besides, Wodak (2005) explains that according to the discursive strategy, predication Modi describes the in-group positively in which Modi portrays the ingroup as a responsible party in making the election a success. 


\section{Excerpt 4: Predication, Directives}

63 BJP is committed to changing India's future! This election, let us VOTE FOR INDIA

242 Asked people why is there so much poverty in a rich land like Assam. Urged them to reject those who made Assam poor by their misgovernance.

339 Asked Karnataka to vote for India's development \& uproot Congress, which stands for corruption \& misgovernance

530 Urged people of Nanded to defeat the 'Adarsh candidate' of Congress, who has played with emotions of widows of Kargil martyrs.

Based on the excerpt above, speech acts of directives is spotted. The word vote (sentence 63) denotes a person to register a vote during elections. Modi directs citizens to vote for the national elections in India. Modi advised Indian citizens to vote for him as his leadership qualities are reflected in the development work that he has done in Gujarat, which has changed the future of Gujarat. This is because Gujarat is the number one state in terms of progress under the leadership of Modi. Hence, as a political leader, he has contributed to the development and thus will continue to contribute to the development of the nation.

Another lexical choice employed in the tweets of Modi is the employment of the word reject (sentence 242), which is synonymous with the word uproot (sentence 339). Reject and uproot mean to eliminate or discard something off the familiar location. During the national elections in India, Modi has expressed his criticism towards the opposition party who has caused misgovernance in various aspects, including finance, administration, economics, and other prominent part of Indian politics. Furthermore, the directives by Modi portray the negative otherpresentation by Modi towards the out-group while indicating a positive image of BJP, which is the ingroup.

The portrayal of negative other-presentation is about the discursive strategies by Wodak (2005), who states that social actors are described negatively to exhibit their weakness, which jeopardizes their reputation among the citizens. Besides, Searle (1979) and Thomas (1995) elucidates that directives are a speech act classification whereby politicians are commanders who direct the citizens to perform an action that is within their boundary. Meanwhile, Austin (1962) perceives speech act directives as utterances that are channeled to the listener to get the listeners to execute the exact message that is being delivered by the speaker. In this classification of speech acts, Modi, as the speaker, directs the citizens to provide a mandate to BJP and to reject the opposition party to gain success.

Under the hood of CDA, a prominent aspect that is worth investigating is the emergence of main discourse topics in the tweets of Modi. The purpose of investigating discourse topics in the political realm is to provide specific elaboration of the election campaign. Besides, CDA reveals how Modi manipulates the minds of citizens through extensively deliberating topics during national elections. The various types of topics that emerged during national elections in India have investigated through Brown and Yules' (1983) topic framework about the concept of nation-building. Wodak's (2005) discursive strategies are employed to classify the topics found in the elections tweets.

\section{Excerpt 5: Predication, BJP, and Publicity}

40 The Dialogue was a memorable experience. I am very glad \& reassured about the future of India

224 People say political parties want power. BJP wants power, but it wants power to empower the people. Power for BJP is the empowerment of people.

Based on the excerpt above, the topic of BJP and publicity emerged during the national elections. The emergence of this topic is vivid through the lexical choices I (sentence 40), BJP, empower, and power (sentence 224). Modi has notoriously gained publicity across India and internationally during the general elections in India in 2014. The ultimate purpose of publicizing BJP in the global arena in Twitter is to obtain a diplomatic relationship between other countries in various aspects, which will enhance the development of the party. The word I signifies BJP as Modi is the head of the political party. Being part of the political party, Modi intends to assure citizens and diplomats of their political propaganda about the concept of skilled India. Besides, the word I refers to the term independent whereby, as an independent party, Modi believes that his party can autonomously build a successful nation. 
The word power represents the ability to influence the behavior of people in the social structure. During the national elections, Modi legitimizes power upon the citizens as a means to portray good governance. Besides, the concept of power exhibited by Modi signifies the authority that he possesses in aiding the citizens to be successful. Modi intends to empower poor citizens by providing facilities that are free of cost. BJP's main concern lies in the aspect of poor publicity of the state and the central government in which the beneficiary scheme to the deprived groups has not been allocated accordingly. Hence, BJP is committed towards all-rounded development of the country, and this has shaped a positive image of the party. At the same time, this provides an opportunity to attract citizens in believing and voting for BJP.

Speech acts of commissives and directives collaborated under the hood of discursive strategies of predication and perspectivation. These speech acts work together to empower Najib to be a nationalist that helped him to establish a profound contact with the citizens while creating a sense of integration and oneness. Furthermore, the speech act of directives was dominantly employed to request citizens to vote for Najib to establish an identity among the citizens. Commissives' lexical choices such as pledge, promise, and committed reflected future actions, which will be undertaken by Najib to form a resilient nation. Besides, the directive lexical choices such as to give, follow, and share portrayed the authority of Najib as a leader democratic leader to influence citizens with instructions to elect him as a PM. Speech acts of commissives and directives were consolidated together with Wodak's (2005) discursive strategies of predication and perspectivation whereby Modi established a harmonious relationship between him and the citizens while describing the in-groups positively and out-groups negatively. The speech acts of commissives were employed to portray that Modi will engage in future actions that will benefit the citizens. Lexical choices that reflected future actions such as committed, help, promise, and will portray that the concept of nation-building will be enhanced. The lexical choices that portrayed directives such as vote reject, uproot, and urged demonstrated the authority of Modi in leading the citizens to emerge as a successful political leader.
Through the use of speech acts, consensual power was exhibited whereby citizens were influenced by Modi's discourse to vote for him.

The findings of discursive strategies demonstrated that there was a relation between the exercise of power by consent (Simpson \& Mayr, 2010) between Najib and the citizens. The mutual agreement through power portrayed that citizens accepted the superior's discourse in aspects such as metaphors, and speech acts benefited the citizens in various aspects. Through consensual power, Najib has gained a more stable positions among the citizens who are willing to support him as a leader for a better future. Modi's use of discursive strategies like his use of speech acts showed persuasive influence. His followers are persuaded into accepting and agreeing with his ideologies for nationalism. Modi's discourse showed the use of consensual power that is the use of power by dominance and consent, whereby he coaxes his citizens into approving and being in harmony with him and his belief.

\section{Conclusion}

Tweets that were broadcasted on Twitter newsfeed during the election campaigns in Malaysia and India are often found to be sensational to readers as election scenarios conveyed voices of the political figures governing each respective country. About the national election campaigns, this study was initiated to explore the tweets in the perspective of language between two distinguished political figures in Asia, namely Najib and Modi. This study investigated the illocutionary acts of commissives and directives, which were collaborated with Wodak's discursive strategies to observe how political leaders employed intended meaning in portraying future actions and steering the citizens to a better future. The findings of this study have shown the concept of power by consent, whereby citizens are willing to accept and obey instructions given by leaders to a better future. Also, the findings of this study will further contribute to the existing literature on political discourse and language in inculcating citizens with political knowledge.

\section{Acknowledgments}

This work would not have been possible 
without the financial assistance of Grant PutraInisiatif Pensyarah Siswazah (IPS), Vot No: GPIPS/2015/9450700, Universiti Putra Malaysia (UPM). We are grateful to all those who have contributed and assisted towards the completion of this research.

\section{References}

Austin, J. L. How to Do Things with Word, Oxford University Press, New York, 1962.

Fromkin, V., and Thomas, R. An Introduction to Language. Orlando: Harcourt Brace College Publishers, 1998.

Ilyas, S., and Khushi, Q. "Facebook Status Updates: A Speech Act Analysis." Academic Research International, vol. 3, no. 2, 2012, pp. 500-507.

Liedtke, F. Representational Semantics and Illocutionary Acts. "Speech Acts, Meaning, and Intentions. Critical Approaches to the Philosophy of John R. Searle. de Gruyter, Berlin/New York, 1990, pp. 194-209.

Mišićilić, B., and Radulović, M. "Commissives and Expressive Illocutionary Acts in Political Discourse." Pragmatics, vol. 11, no. 1, 2015, pp. 19-49.

Nastri, J., Pena, J., and Hancock, J. T. "The Construction of Away Messages: A Speech Act Analysis." Journal of Computer-Mediated Communication, vol. 11, no. 4, 2006, pp. 1025-1045.
Pandey, Rishikant. Speech Act and Linguistic Communication. India: Concept Publishing Company, New Delhi, 2008.

Searle, J. R. Expression and Meaning: Studies in the Theory of Speech Acts. Cambridge University Press, Cambridge, 1979.

Searle, J. R. Speech Acts: An Essay in the Philosophy of Language. Cambridge University Press, Cambridge, UK, 1969.

Sotillo, S. M. Illocutionary Acts and Functional Orientation of SMS Texting in SMS Social Networks. Studies in Variation, Contacts and Change in English, vol. 12, 2012.

Thomas, J. Meaning in Interaction: An Introduction to Pragmatics. Pearson, London, 1995.

Vanderveken, D. Meaning and Speech Acts: Volume 1, Principles of Language Use. Cambridge University Press, Cambridge, 1990.

Wodak, Ruth. "Feminist Critical Discourse Analysis: New Perspectives for Interdisciplinary Gender Studies." Symposium on CDA: Feminist CDA and Interdisciplinary; Righwing Populism Local Answers to Global Issues, Athens, 2005.

Yule, G. Pragmatics. Oxford University Press, Oxford, UK, 1996.

Zhang, R., Gao, D., and Li, W. What Are Tweeters Doing: Recognizing Speech Acts in Twitter. Analyzing Microtext, 11, 2011, pp. 86-91.

\section{Author Details}

Renugah Ramanathan, Department of English, Faculty of Modern Languages and Communication, Universiti Putra Malaysia, Selangor, Malaysia, EmailID: renugah02@hotmail.com.

Shamala Paramasivam, Department of English, Faculty of Modern Languages and Communication, Universiti Putra Malaysia, Selangor, Malaysia, Email ID: shamala@upm.edu.my.

Tan Bee Hoon, Department of English Language and Communication, Faculty of Social Science and Liberal Arts, UCSI University (Kuala Lumpur Campus), Malaysia,Email ID: tanbh99@yahoo.com. 